\title{
SOCIAL INTEREST IN FINANCIAL REGULATION AND THE CONSTITUTIONAL PRINCIPLES
}

\author{
AKSANA SHUPITSKAYA ${ }^{1}$
}

\begin{abstract}
This article deals with financial regulation is a major activity of the state, whose goal is the definition of order in the important sphere of social activity - the sphere of accumulation and distribution of state funds. This activity is carried out in the interests of society and of each individual member. The main aim of the contribution is to confirm that the financial regulation is kind of the state action based on the Basic law of the state - its Constitution. The Author concluded that the objectives of these activities, its directions, forms and methods are based on the constitutional principles, establishing the scope of this activity in order to achieve a balance between public and private interests. The main method used by the Author is the analytical method.
\end{abstract}

\section{Keywords}

Financial regulation; Constitution; constitutional principle; public interest; private interest

JEL Classification: D63, K00, K10

\section{Introduction}

Financial regulation is a kind of state-legal activity aimed at public relations related to the state's finances. No state can realize its internal and external functions, ensure the implementation of social and economic programs without having sufficient funds for this, without having the financial resources. The purpose of this work is to

1 Docent, Associate Professor of International Law Department, Educational Institution Janka Kupala State University of Grodno, Belarus. The Author specializes in constitutional law. She is a member of Center for the Research on the Public Finances and Tax Law in the Countries of Central and Eastern Europe. Contact email: oshupitskaya@mail.ru. 
analyze the financial activities of the state in terms of the constitutional principles of democracy, sociality, humanism, etc. The hypothesis investigated the Author, - the constitutional principles define the directions, forms, methods, borders of activity of legislative bodies, the law-enforcement activity of the state institutions in the sphere of financial regulation, act as criteria for the resolution of legal conflicts, coordinate public, and private interest. The analysis method was used as the main research method. Public and private interest, including in the field of financial regulation was studied in the works of Y.A. Tikhomirov (1995); G. Vorobey (2012). Constitutional principles are the subject of interest of such researchers as A.A. Liverovskiy (2015, 2017).

\section{Financial Regulations and Social Interests}

Financial regulation is the activity carried out by objective necessary. This need, according to G.A. Vorobey (2012: 5), is the need to distribute and redistribute national income, to meet the needs of individual citizens, society, and the state. Regulating and guiding the cash flows, forming monetary funds subsequently spent on the needs of society, the government can stimulate the activity of certain areas of production or reduce it. The state authorities play the decisive role in the direction and implementation of the state financial activities. They approve budgets and performance reports, delineating income and expenditures between different budgets, establish and cancel taxes. Financial activity of the state is mostly management activities at its core.

State bodies, carrying out financial activities through, including its legal regulation, implement certain interests. Interests express the social claims of the most socially active strata of society. The fixing in the law of socially significant interests is relevant to the objective interests of society, is crucial in achieving social peace in the state. It is obvious that the protection of the interests which are not satisfying objective interests of the whole society leads to the violation of their balance and threatens to the public order. Here the most important social task is the harmonization of different interests, compromise, ensuring social cohesion and partnerships. This challenge decides by the public authorities on behalf of the people.

The law initially reflected the interests of society as a totality of its members (all or a dominant portion thereof) and the interests of each individual (or certain members). Social interest is a kind of average interest. The dialectic of the relationship of social and private interest is as follows: the social interest is formed by eliminating private interest from the totality of the interests, but private interest could not be 
Social Interest in Financial Regulation and the Constitutional Principles

implemented without social interest. The social interest is necessary for a balanced sustainable development of the state and society.

In scientific literature, it is often asserted that the public and private interests create the basis of public administration. Public interest considered the interest of the public. Private interest considered the interest of individuals or corporations. One of the important issues in this regard is the question about the coincidence of the social and the public interest. Public interests, as well as the social, defined as a kind of averaging of personal and group interests. It is the interests, without which it is impossible to ensure the integrity, stability, normal development of the state and society as a whole. As can be seen from these factors, public interests and social interests are one and the same. However, public interests have the distinctive feature - its formal character. They are the interests that are recognized by the state, have its support and protection. Consequently, the public interest is, as correctly claimed by Y.A. Tihomirov (1995: 55) recognized by the state and law secured interests of the social community, the satisfaction of which is a condition and guarantee of its existence and development.

The role of the state in implementation of social (public) interest is extremely important. Social interest is the interest of multi-level social groups. It is the interest of people united in political parties. It is the interest of people united in trade unions. It is the interest of territorial communities of people - people living in the regions, cities, small towns. The state, as is known, represents the society. Thus, social (public) interest becomes the public interest. These interests are realized in different spheres of life: economic, political, ideological, and social. So, for the normal functioning and development of the economy, the state protects all forms of ownership, ensures the development of production, organizing external relations. In order to ensure public order, the state protects its territory and sovereignty from external attack, suppresses the resistance of the opposing social forces, is taking steps to find a national and general agreement. The government supports education, science, culture, expands the state ideology in the ideological sphere. Through public branches of law - constitutional, administrative, criminal, financial, etc. the state regulates activities in areas governed the specified branches of law, makes it certain regulations, controls and protects it.

Government regulation is specific. In the sphere of implementation of public interest the state uses mainly the imperative method of legal regulation, i.e. a method of power and subordination. If necessary, the state establishes certain prohibitions. The state has the right of coercion, allowing him to effectively influence social relations. Thus, the state is a powerful mechanism of realization of interests. But the question arises: "Is it always the state supports and protects social in their essence interests?" After all, the state is also its bodies, officials and decision makers on behalf of the 
society, on behalf of the people. The experience of many countries knows many examples, when under the guise of the public, social interest private interests of corporations and social groups, bureaucratic interests, personal interests of public servants who abuse the right were implemented. The obvious conclusion is that the state in order to ensure the interests of each, without prejudice to the freedom of any of its members, should be organized in such a way so to limit, if not eliminate completely, this kind of manifestation. Legislative and enforcement bodies perform the problem of determining the social interest and distinction between them and private interests in the sphere of financial regulation. The state Parliament as the supreme representative body of the country passes laws, determines bases of legal regulation in the financial sector of the country as a whole. Local authorities by issuing normative acts regulate these issues at the regional level. In Belarus, for example, among the most important legislative acts adopted by the National Assembly of the Republic of Belarus (the Belarusian Parliament) are the Tax code of the Republic of Belarus (General part), the Tax code of the Republic of Belarus (Special part), the Budget code of the Republic of Belarus, the Banking code of the Republic of Belarus, the Investment code of the Republic of Belarus, the annual Act On the State Budget, etc. The President of the Republic of Belarus as the Head of the State has the special place in system of bodies of the Belarusian state involved in financial regulation. Belarusian President signs the laws related to financial legislation, issue decrees and orders on the issues of taxation, foreign currency transactions and other matters, carries out preliminary control of the main financial plan of the state of the draft national budget, establishes the fundamentals of financial control in the country. Local Councils - local authorities - confirm the local budget, establish local taxes and fees, determine the manner of disposal of municipal property. Executive-regulatory authorities of the state decide the issues arising in the process of implementation of the law, the use of the state coercion. The Government of the Republic of Belarus - the Council of Ministers - ensures the execution of the Republican budget income, makes decisions on taxation. A significant part of the authority of the Ministry of Finance of the Republic of Belarus, Ministry for Taxes and Levies of the Republic of Belarus, the State Control Committee of the Republic of Belarus, the National Bank of the Republic of Belarus, local executive and administrative bodies is also linked to the financial sector.

Violations of the balance of public and private interests are possible at the stage of legislative activity, and in particular, at the stage of enforcement. The court could and should to restore to the specified balance. The constitutional justice body can do it by considering the conflicts between normative legal acts. The general court can do it by solving the different categories of legal disputes. The Constitutional Court of the Republic of Belarus exercises control over the conformity of laws, decrees 
Social Interest in Financial Regulation and the Constitutional Principles

and edicts of the President of the Republic of Belarus, international contractual and other commitments of the Republic of Belarus, other normative legal acts to the Constitution of the Republic of Belarus and international legal acts ratified by the Republic of Belarus. The system of courts of general jurisdiction, including district, regional (Minsk City), economic courts of areas (Economic Court of Minsk), the Supreme Court of the Republic of Belarus shall administer justice on criminal and administrative cases, civil, family, labor, economic, and other disputes.

The solution to such global challenges as achieving conformity between the social and the public interest appears to be possible only in the conditions of realization of the most important principles of the law - the constitutional principles. The constitutional principles are the elements of the law that have a natural origin. The fundamental constitutional principles are initial ideas, accepted by people and/or anchored in the text of normative legal acts. They are the components of database regulation of social relations. The fundamental constitutional principles create a system of interconnected influence on the constitutional development of the society. They operate in a specific social space and time, handling social relations through the formation of democratic institutions that ensure the interaction of man, society and the state, the individual and social groups. As a legal matter, the constitutional principles are the universal, universally valid, imperative. The main task of the constitutional principles is to determine the direction of constitutional regulation of social relations in each historical and legal moment.

\section{Constitutional Principles and Social Interest}

The system of fundamental constitutional principles defines the basis of the content of any of the Constitution (the constitutional model) (Liverovskiy, 2017: 187). Concretization of the constitutional principles, their existence as a law is a conscious decision of the people through the adoption of the Constitution as the Fundamental Law of the state. Thus, the legal form of social development, the state constitutional path is determined. From the point of view of A.A. Liverovskiy (2015: 7-9), the constitutional model is constructed in such a way that the components of its fundamental constitutional principles implementing the supreme constitutional values. The constitutional principles not only define the legal the state of society but also to some extent determine its constitutional development by mediating the different values within a "pyramid" of social values, "headed" by the higher one. The Constitution of the Republic of Belarus and the Constitution of the Russian Federation considered the Man as the highest value. Man is the Supreme value and goal of the state and society according to the Art. 2 of each Constitution (Constitution of the Republic of Belarus of 24 November 1996; Constitution of 
the Russian Federation of 12 December 1993). Constitutional principles define the principles of the social structure of the society and implement its values. It is logical to assume that there are social values that can be universal for any community, belonging to the population of the state and living on its part, autonomous in some sense to it. Such values, at least according to scientists, are the highest constitutional values, such as "human dignity".

The constitutional principles, as the law in general, provide interaction of human being, society, and the state. The regulation of social space on the basis of modern constitutional models is carried out in a man-centered paradigm. So, the meaning and content of activities of public authorities are to protect the rights and freedoms of the individual, that is, in the realization of the highest constitutional values of the Constitution. The constitutional principles operate within the boundaries of a particular social space and social time. Because their meaningful and long-term use leads to a sustainable sense of justice of people, substantial change of the constitutional model leads to serious social upheaval. At the same time, the very set of constitutional principles is a developing system which characterized by integrity and sustainability.

The constitutional principles perform several important functions in relation to the legal regulation, including the financial sphere of social relations. Functions of constitutional principles are the main directions of their influence on social relations that reflect their subject characteristics. Directions of the impact of the principles of law on social relations persist for centuries. But, according to N.V. Silchenko (2004: 40 ), "change the contents of the social relations regulated by law changing ways, forms, and means by which law influences on social processes". Functions of the constitutional principles can be divided into social and actually legal.

The implementation of the social function by the constitutional principles follows from the fact that the law is a social phenomenon that has arisen in society and provides a significant impact. This effect is in relation to the state and against the institutions of society, and in relation to the individual. The constitutional principles play an important role in the organization and functioning of the state, because they control the system of state bodies, their relations, and fix their order formation and action. Such principles of the Constitution as democracy and separation of powers are obviously of this feature in. Such basic ideas of the Fundamental Law as humanism or democracy clearly show another function of the constitutional principles in relation to the state - the function to be the instrument of communication with society, its citizens, and their groups.

Social functions of the principles of the Constitution are also the directions of their effects on the individual. Thanks to the constitutional principles the citizens learn 
about the nature of law, existing in the national legal system in the specific historical stage of its existence, the content of its components. This is especially true in the case of such constitutional principles as equality or controllability, for example. By means of constitutional principles, individuals get information about recognized in this society social values that allow them to build their behavior according to them.

The fundamental constitutional ideas aimed at strengthening the existing social relations. They have a stabilizing effect on social connections that are within the scope of their regulation. They are designed to ensure the development of social relations which are in constant motion, presenting a dynamic part in the bunch of "law - society". The constitutional principles also protect social relations in the case of the threat to them. Named functions of the constitutional principles can be viewed as legal. And they should be analyzed in more details.

The system of the constitutional principles that govern financial regulation and, therefore, set the balance between public and private interests in this area includes such fundamental ideas as humanism, democracy, sociality, the separation of powers, equality, controllability, etc. The recognition, observance, and protection of the rights and freedoms of the individual are the essence of the principle of humanism - the most important basic idea underlying the organization and functioning of the modern state. This principle, at first glance, seems moral. However, defining legislative and law enforcement bodies of the state, sometimes fixed on the level of legal norms and sometimes inferred from their contents, it is an essential principle of organization, functioning, limitation, the kind of scale of the state and its bodies. The idea of humanism is also the measure of the state institutions activities. This principle should underlie the legal expertise of the normative legal acts that regulate social relations in the financial sector, preliminary examination of normative acts carried out by the body of constitutional justice if any in the state. For example, the preliminary normative control exercised by the Constitutional Court of the Republic of Belarus in the Belarusian state. In the analysis of activities of law enforcement bodies, their decisions in the field of financial regulation, the assessment of their activities, the resolution of disputes arising in the field of social relations an observance of the principle of recognition and protection of the rights and freedoms of man must be rigorous.

One more important principle governing the financial activities of the state is the principle of democracy. The idea of democracy enshrined, for example, in the Art. 3 of the Constitution of the Republic of Belarus. According to it the people is the only source of state power and bearer of sovereignty in Belarus. The people exercising their power in defined forms. The principle of democracy means that the people are the subject of public authority, acting as the totality of the whole population. The object of the people's power is all social relations of public interest across the 
country. The power of the people has primacy in relation to all other forms of power. The people exercise the fullness of power belonging to him in two forms: directly and indirectly. Direct democracy is the referendum and the elections. Mediated expression of the will or interests of individuals is expression it through a specially created state bodies or bodies of public associations. Democracy is exercised through both of these forms in the finance sphere. The people directly elect the state bodies (higher and local) which have an authority in the field of publication of the law regulating the financial activity of the state. The government, ministries, executive committees are the specialized bodies that regulate financial activities on behalf of the state in the interests of all people. The question arises, can there be a contradiction between the people and the state authorities formed by them or on their behalf? Obviously, yes. And in this connection special importance has the resolution of this potential conflict through the established ways but in the interests of the person.

Another important constitutional principle which defines the legal regulation in the financial sector is the principle of sociality. The social state is manifested in caring for the person, the support of the social strata that are unable to provide for themselves - children, the elderly, the disabled and mothers with children. The sociality of states also is the latter's pursuit of uniform and equitable distribution of vital goods. The given path resolving and mitigating social contradictions in society. It creates equal opportunities in the provision of material well-being and satisfaction of spiritual needs for all members of society. In the regulation of social relations connected with financial resources of the state, sociality as the constitutional principle manifesting in the establishment of differentiated tax rates, the incentives to certain categories of persons and (or) income received by them, etc. The balance between public and private interests in the implementation of social tasks of the state, on the one hand, promotes economic development, increase production and incomes. On the other hand, it allows preventing the critical gap between the wealthy and the poor or unsecured members of society.

The separation of powers as a constitutional principle is a specialization of state bodies in the activities. As correctly noted by A.A. Bezuglov and L.L. Belomestnyh (2004: 162), based the separation of powers, state bodies vested with a specific competence. They are autonomous and independent in exercising their powers and have the potential to mutually constrain each other. However none of the branches of power may assume the functions of the other branches of power, but to act in isolation they may not too. The existence of legislative, executive and judiciary branches of power - the so-called horizontal dimension of the principle of separation of powers - is clearly described in modern Constitutions - Fundamental Laws of states. The vertical aspect of the separation of powers is no less important. It means 
that the United States power demarcates the subjects of conducting and power between state authorities of federation and state bodies in terms of federations, as well as between central state bodies and local authorities and administration as in federal states or in unitary states. What about the financial regulation of social relations, the separation of the powers between the central and local authorities in terms of setting taxes and fees, their collection and distribution, as well as in the execution of various types of the budget (national and local, for example) is using.

Equality is the universal phenomenon, the idea, the proclamation of which is associated with the period of bourgeois revolutions, the adoption of the first legal acts regulating the basis of the legal status of the individual, including Habeas Corpus Act, the French Declaration of the Rights of Man and Citizen, the Constitution of the United States of America, etc. The basic meaning of this principle is that men are born and remain free and equal in their rights. This applies to all areas of social relations. Equality means that each subject of the state is provided by the equal legal opportunities with other members that the law imposes equal responsibilities, and realization of the rights and duties provided to him on an equal footing. Equal duties are no less important than equal rights. The establishment of equal rights and obligations in the financial sector, equal protection of financial entities, equal responsibility in the case of the offense in the specified area, etc. is the manifestation of the principle of equality in the sphere of financial regulation aimed to balance social and private interest.

The principle of controllability is the idea of great importance in the field of economic and monetary relations of the state. The control is the verification of the results of the social activities in accordance with aims and norms of organizations, communities, states, and universal values. The control is realizing towards the activity of individuals, their professional and spatial community organizations and the state. In the financial sector the legal acts issued by the authorities, their implementation, the realization of legal norms that establish the legal liability in case of committing financial offenses are controlled. Financial control covers all social relations arising in the sphere of financial activities of the state, ensuring the legality and appropriateness of financial policies. The control is intended to prevent the mismanagement and extravagance, to establish the facts of theft of inventory and fraud in this area.

\section{Conclusions}

The manifestation of public and private interest in the process of financial regulation of social relations is inevitable. It is sometimes very difficult to separate the public and private interest because the boundary between them is movable. It is defined 
by the legislator on the concrete historical stage of the legal system development. And the task of the legislator is to balance public and private interest by means of legal regulation. The contradictions could be between the various private and public interests. In some cases, it is the contradictions between legal and illegal interests. In others, contradictions between the legal, but misunderstanding interests of one of the subjects. The legal method (way) has the special importance for both types of contradictions resolution. But the procedure of the consultation and coordination of interests are also very effective.

The coordination of public and private interests in the sphere of financial regulation is carried out through the implementation of the constitutional principles of humanism, democracy, sociality, separation of powers, equality, controllability, etc. These principles determine the directions, forms, methods, the boundaries of the activity of legislative authorities in this area, enforcement of state institutions, act as criteria to resolve legal conflicts.

\section{References}

Bezuglov, A., Belomestnyh, L.: Конституционное право России (Constitutional law of Russia), Moscow: Publishing House AAFP, 2004.

Liverovskiy, А.А.: Право Конституции (Law of the Constitution), in: Методология современного конституционализма: конституционализация позитивного права, конституционная аксиология пропорциональности: материалы XIV Международной научнопрактической конференции по конституционному праву (Methodology of modern constitutionalism: the constitutionalization of positive rights, constitutional axiology of proportionality: proceedings of the XIV International scientific-practical conference on constitutional law), St. Petersburg: Saint-Petersburg state University of Economics, 2017.

Liverovskiy, А.А.: Правопонимание в конституционной юстиции (Understanding of law in the constitutional justice), Конституционное и муниципальное право (The Constitutional and municipal law) no. 6 (2015).

Silchenko, M. et al.: Общая теория права (General theory of law), Grodno: GRGU, 2004.

Tihomirov, Y.: Публичное право (Public law), Moskow: C.H. Beck,1995.

Vorobey, G.: Финансовое право Республики Беларусь: учебный курс (Financial law of the Republic of Belarus: study guide), Minsk: Amalfeya, 2012.

BY: Constitution of the Republic of Belarus of 24 November 1996.

RU: Constitution of the Russian Federation of 12 December 1993. 